JINOTEP Vol 8 (1) (2021): 47-57

DOI: $10.17977 /$ um031v8i12021p047

JINOTEP (Jurnal Inovasi Teknologi Pembelajaran)

Kajian dan Riset Dalam Teknologi Pembelajaran

http://journal2.um.ac.id/index.php/jinotep/index

\title{
ANALISIS DATA RESPON MAHASISWA TERHADAP SISTEM PEMBELAJARAN BERBASIS MOOCS PADA MATAKULIAH ILMU LINGKUNGAN MENGGUNAKAN RASCH MODEL
}

\author{
Eko Risdianto, Ahmad Syarkowi*, Dewi Jumiarni \\ Universitas Bengkulu-Bengkulu
}

\begin{tabular}{l}
\hline Article History \\
\hline Received: 05-11-2020 \\
Accepted: 06-1-2021 \\
Published: 1-03-2021 \\
Available online: 15-01- \\
2021
\end{tabular}

Keywords

Respon mahasiswa; MOOCs; Model Rasch

\begin{abstract}
Abstrak
Penelitian ini bertujuan untuk menganalisis respon mahasiswa terhadap sistem pembelajaran online berbasis MOOCs. Pengumpulan data dilakukan dengan penyebaran angket yang terdiri dari 14 butir pertanyaan terhadap 20 orang mahasiswa mengenai tanggapan mahasiswa terhadap media pembelajaran yang diberikan. Data dianalisis dengan Model Rasch dan diolah menggunakan software Winstep. Dari data yang diperoleh menunjukkan bahwa kualitas dari angket respon terhadap uji coba terbatas pengembangan pembelajaran ilmu lingkungan menggunakan sistem MOOCs ini adalah sangat baik. Sehingga dapat digunakan untuk menguji coba terbatas pengembangan pembelajaran ilmu lingkungan menggunakan sistem MOOCs. Dan dari hasil analisis terhadap responden dan item butir angket menunjukkan bahwa mayoritas responden menyetujui semua butir angket yang diberikan sehingga menunjukkan bahwa pengembangan pembelajaran ilmu lingkungan menggunakan sistem MOOCs ini layak digunakan dan dapat digunakan secara lebih luas untuk mata kuliah yang lain khususnya dalam pembelajaran daring di masa covid 19 saat ini.
\end{abstract}

Abstract
This study aims to analyze student responses to the MOOC-based online learning
system. The data collection was carried out by distributing questionnaires
consisting of 14 questions to 20 students regarding student responses to the given
learning media. Data were analyzed using the Rasch Model and processed using
Winstep software. From the data obtained, it shows that the quality of the response
questionnaire to the limited trial of environmental science learning using the
MOOCs system is very good. So that it can be used to study the limited trial
development of environmental science learning using the MOOCs system. And from
the results of the analysis of the respondents and the questionnaire item items, it
shows that the respondents who gave all the questionnaire items showed that the
development of environmental science learning using the MOOC system was
feasible and could be used more widely for other subjects, especially in online
learning in Covid 19 pandemics this time.

Corresponding author: Ahmad Syarkowi

2021 Universitas Negeri Malang p-ISSN 2406-8780

Adress: Jalan WR. Supratman Kandang Limun,Bengkulu e-ISSN 2654-7953

Instansi: Universitas Bengkulu,

E-mail: ahmadsyarkowi@unib.ac.id 
48 JINOTEP (Jurnal Inovasi dan Teknologi Pembelajaran) Kajian dan Riset dalam Teknologi Pembelajaran Vol. 8, No. 1, Maret 2021, Hal. 47-57

\section{PENDAHULUAN}

Perkembangan Ilmu Pengetahuan dan Teknologi (IPTEK) saat ini telah memberikan pengaruh dalam semua bidang kehidupan manusia (Sintia et al., 2018). Manusia di era sekarang ini dihadapi dengan revolusi industri 4.0 yaitu Era Cyber-Fisik (Risdianto et al., 2020). Perkembangan revolusi industri 4.0 muncul dimulai dengan digitalisasi sistem pendidikan yang mengarahkan setiap unsur dalam bidang pendidikan dalam upaya melakukan penyesuaian dengan laju perubahan yang terjadi (Siahaan et al., 2019).

Setiap zaman akan selalu ada perubahan yang mengarah pada kemajuan pendidikan dikarenakan adanya berbagai inovasi(Peranti et al., 2019). Begitupun dengan era revolusi industri 4.0, era ini secara langsung berdampak pada dunia pendidikan di Indonesia (Risdianto, 2019). Peningkatan mutu pendidikan merupakan fokus utama bagi setiap negara saat ini begitupun dengan negara Indonesia, banyak strategi dan upaya yang telah dilakukan pemerintah dalam rangka meningkatkan mutu pendidikan itu sendiri (Sriwahyuni et al., 2019).

Salah satu upaya yang sudah mulai dilakukan yaitu adanya pengembangan media pembelajaran. Media pendidikan atau media pembelajaran meliputi orang, bahan, peralatan, atau kegiatan yang menciptakan kondisi yang memungkinkan siswa memperoleh pengetahuan, keterampilan dan sikap (Johar et al., 2014). Media pembelajaran merupakan komponen yang dapat membangkitkan motivasi dan minat siswa (Putri et al., 2019). Pengembangan suatu media pembelajaran selalu mengikuti perkembangan zaman. Pada era 4.0 ini proses belajar tidak dapat lagi dibatasi oleh waktu maupun ruang. Saat ini banyak berkembang pembelajaran daring yang menjanjikan kualitas sama dengan pembelajaran tatap muka. Melihat peluang ini banyak platform yang menyediakan jasa template dan juga desain pembelajaran daring misalkan Moodle, google classroom, dan lainnya. Disamping itu bisnis pembelajaran online ini juga menjadi lirikan oleh kampus-kampus besar dalam memberikan kursus online.

MOOC merupakan salah satu inovasi terbaru dalam dunia pendidikan yang berkembang pesat
(Busri et al., 2019). MOOC adalah akronim dari Massive Open Online Course. Kulah ini didasarkan pada prinsip eksplisit connectivism (otonomi, keanekaragaman, keterbukaan dan interaktivitas) pada kegiatan agregasi, remixing, repurposing dan memberi umpan balik pada setiap interaksi sumber daya dan pembelajaran (Rodriguez, 2012). MOOC pertama kali diperkenalkan pada tahun 2006 dan muncul sebagai mode pembelajaran yang populer pada tahun 2012 (Husna, 2019). MOOC menawarkan kursus secara terbuka dan meluas di mana pembelajaran, perbincangan, komunikasi dan interaksi dilakukan secara aktif (Azri et al., 2020). Sebagai dampak dari kemajuan teknologi yang sangat pesat, kursus di MOOC dirancang dengan referensi teori belajar yang berbeda, yang dapat memenuhi kebutuhan pelajar (Rafiq et al., 2019). Terdapat tiga konstruk utama yang menjadi asas dasar dalam mengembangkan dan menggunakan MOOC. Elemen-elemen ini termasuklah kurikulum yang dicadangkan, kurikulum yang dilaksanakan dan kurikulum yang dicapai (Ismail, Hashim, et al., 2018). Nuansa MOOC telah memperluas pembelajaran online menjadi skala besar di seluruh dunia, serta menghadirkan peluang baru serta tantangan baru (Praherdhiono et al., 2018).

Penggunaan MOOC terutama di kalangan akademisi membantu meningkatkan motivasi dan minat di antara siswa yang masih memudar dalam pembelajaran berbasis e-learning (Ismail, Utami, et al., 2018). Ada dua karakteristik model MOOC yaitu; 1) Pemanfaatan jaringan internet dan web sebagai sarana dalam kegiatan pembelajaran jarak jauh. 2) Adanya jumlah peserta banyak dan skala pembelajaran yang besar (Johan, 2016). Kuliah online ini mulai di luncurkan pada 2010 oleh Dave Cormier (Cormier et al., 2010). MOOC merupakan hit terbaru dalam pembelajaran online, dan diposisikan sebagai alternatif untuk program pendidikan tinggi tradisional (Emigawaty, 2017). MOOC menjadi sangat populer ketika Stanford University menggunakannya untuk memberikan kuliah online tentang kecerdasan buatan (Artificial Intelligence) $(\mathrm{Hu}, 2013)$. Melihat sukses besarnya Stanford University mulailah banyak kampus besar yang 
menggunakannya. bahkan adalah satu kampus terbaik dunia Harvard dengan launching platform Moocs (Massive Online Open Courses) yang diberi nama edX (https://www.edX.org/).

Fenomena maraknya pembelajaran Moocs membuat banyak investor tertarik dan mendesak universitas-universitas untuk mengembangkan hal yang serupa (Yuan \& Powell, 2013). Terhitung sejak 8 tahun pelaksanaan, Pada tahun 2019 tercatat ada 110 juta pengguna, tidak termasuk China, dengan lebih dari 2.500 kursus dan 11 online degree dan 170 Microcredentials (Shah, 2019). Perkembangan yang sangat luar biasa ini membuat beberapa kampus di indonesia mengembangkan hal yang serupa. Universitas Bengkulu turut berpartisipasi dalam mengembangkan hal ini.

Perkuliahan yang dikembangkan merupakan pembelajaran ilmu lingkungan. Ilmu lingkungan menjadi pilihan dikarenakan kemungkinan untuk dikontrak oleh beberapa program studi dalam rangka mengimplementasikan kebijakan merdeka belajar kampus merdeka. Sebagaimana salah satu pokok kegiatan pembelajaran MBKM adalah memberikan kepada mahasiswa untuk kuliah diluar prodi selama 3 semester (Arifin \& Muslim, 2020). Kesempatan untuk kuliah 3 semester ini sangat bermanfaat dalam menambah wawasan ilmu pengetahuan dan pengalaman belajar mahasiswa sehingga mereka lebih matang dalam menghadapi dunia kerja (Siregar et al., 2020). Di sisi lain Perkuliahan ilmu lingkungan merupakan suatu matakuliah unggulan Universitas Bengkulu dimana terdapat perkuliahan tentang konservasi kura-kura Sumatera yang memang selama ini menjadi salah satu ciri khas kampus ini (Enersy et al., 2017).

Adapun capaian pada pembelajaran ini terdiri dari:

1. Mahasiswa mampu mengumpulkan dan mengolah konsep dan informasi yang berkaitan dengan Ilmu Lingkungan dan mempresentasikannya

2. Mahasiswa mampu mengambil keputusan yang tepat terkait dengan pemanfaatan Sumber Daya Alam, untuk kesejahteraan manusia dari segi sosial, budaya, produktivitas ekonomi, dan keberlangsungan sistem lingkungan
3. Mahasiswa mampu melakukan upaya pemanfaatan limbah di lingkungan sekitarnya sebagai upaya pengelolaan lingkungan yang berkesinambungan

4. Mahasiswa mampu memahami langkahlangkah dalam melakukan Analisis Mengenai Dampak Lingkungan (AMDAL) secara umum

5. Mahasiswa mampu melakukan upaya pendidikan lingkungan bagi masyarakat

Lima capaian ini diturunkan menjadi 7 topik kegiatan pembelajaran yang didesain dengan menggunakan media Moocs. Adapun topiknya adalah pertama Kedudukan manusia dan hubungannya terhadap lingkungan, kedua Prinsip-prinsip/ azas-azas lingkungan dan masalah-masalah lingkungan, ketiga Sumber Daya Alam, keempat Pencemaran, kelima Etika Lingkungan dan Manusia Pembina Lingkungan, keenam Pembangunan Berkelanjutan Berwawasan Lingkungan ketuju Analisis Mengenai Dampak Lingkungan (AMDAL)

Dalam mengembangkan suatu media pembelajaran sangat penting untuk dilakukan ujicoba baik itu ujicoba software maupun ujicoba yang melibatkan responden. Tanggapan para responden terhadap hasil pengembangan sangat penting. Hal ini bertujuan untuk menelaah kelemahan-kelemahan, kelayakan dan sebagai acuan dalam merevisi media. Pada penelitian ini dilakukan pengujian respon mahasiswa terhadap media MOOCs yang telah dikembangkan menggunakan instrumen tes. Data yang diperoleh dianalisis dengan model Rasch.

Model Rasch merupakan suatu penilaian modern yang mampu mengklasifikasikan perhitungan item dan person dalam suatu peta distribusi (Rozeha et al., 2007). Dalam model Rasch, peserta tes dengan kemampuan (ability) tinggi seharusnya memiliki kemungkinan yang lebih besar untuk menjawab benar setiap soal daripada mahasiswa lainnya. Sebaliknya, mahasiswa memiliki peluang kecil untuk menjawab benar suatu soal memiliki tingkat kesulitan lebih tinggi (Sumintono \& Widhiarso, 2015).

Menurut Sumintono \& Widhiarso (2014) kelebihan pemodelan Rasch dibanding metode lainnya, khususnya teori tes klasik, adalah kemampuan melakukan prediksi pada data 
50 JINOTEP (Jurnal Inovasi dan Teknologi Pembelajaran) Kajian dan Riset dalam Teknologi Pembelajaran Vol. 8, No. 1, Maret 2021, Hal. 47-57

hilang, berdasarkan pola respon individu. Keunggulan ini menjadikan hasil interpretasi analisis statistik model Rasch lebih akurat, dan yang lebih penting lagi, pemodelan Rasch dapat menghasilkan nilai pengukuran eror standar pada instrumen yang digunakan sehingga dapat meningkatkan ketepatan perhitungan. Kalibrasi data dilakukan dalam model ini secara sekaligus dalam tiga hal, yaitu skala pengukuran, responden, dan item. Kalibrasi ini mencegah kemungkinan menghasilkan data yang tidak valid dan bisa menyebabkan kegiatan riset yang dilakukan mengalami kegagalan.

Software Winstep merupakan alat bantu perhitungan pada model Rasch untuk menganalisis skor respon yang dihasilkan dari instrumen dengan maksud mengetahui Outfit MNSQ, Outfit ZSTD, Point Measure Correlation, Item reliability dan Alpha Cornbach. Outfit MNSQ bermanfaat untuk melihat kesesuaian data dengan model yang digunakan. Nilai mean square yang diharapkan yaitu 1 (satu). Jika Nilai mean-square pada infit lebih dari satu, variasi dari instrumen lebih banyak dari prediksi yang dapat dilakukan oleh Rasch model. Jika nilai infit kurang dari 1, maka variasi pada instrumen menjadi lebih sedikit jika dibandingkan dengan prediksi yang dilakukan oleh Rasch model (Azizah dan Wahyuningsih, 2020).

Penelitian ini dilakukan bertujuan untuk menganalisis respon mahasiswa terhadap sistem pembelajaran online berbasis MOOCs yang dianalisis dengan Model Rasch menggunakan sofware Winstap.

\section{METODE}

Penelitian ini merupakan bagian dari rangakain penelitian dan pengembangan ( $\mathrm{R} \&$ $\mathrm{D})$, dengan menggunakan desain model ADDIE yaitu pada tahap uji coba terbatas dan untuk mengetahui respon terhadap penggunaan produk yang dikembangkan pengembangan, yaitu sistem pembelajaran MOOCS. Uji coba terbatas dilakukan oleh 20 orang responden yang berasal dari mahasiswa FKIP biologi Universitas Bengkulu dengan teknik pusposive sampling. Teknik pengumpulan data menggunakan angket dengan skala likert modifikasi 7 pilihan jawaban.
Angket yang diberikan merujuk pada 7 indikator tanggapan setelah belajar.

Uji terbatas dilakukan secara daring dengan menggunakan website Moocs yang telah dikembangkan oleh fakultas. Dimana mata kuliah ilmu lingkungan sebagai pilot project. Data angket dikumpulkan tepat setelah mahasiswa menyelesaikan program pembelajaran yang diberikan di website.

Adapun indikator yang menjadi acuan adalah kemudahan untuk dipahami, variasi konten, Ketertarikan, Fokus, kandungan teori, Kemudahan dikuasi, kesesuaian dengan harapan (Korpershoek et al., 2013). Angket tersebut terdiri dari 14 butir pertanyaan. Setiap indikator memiliki 2 pernyataan. Peryataan pertama berkaitan dengan tanggapan positif dan yang berikutnya adalah tanggapan negatif.. angketangket ini yang diisi oleh 20 orang mahasiswa biologi FKIP Universitas Bengkulu sebagai responden uji coba terbatas dengan menggunakan google form.

Data yang diperoleh dianalisis dengan model Rasch menggunakan aplikasi Winstep. Dari hasil analisis data respon yang diperoleh nanti akan tergambar kualitas data angket respon yang meliputi abilitas responden (person), kualitas butir angket, kesesuaian responden yang nantikan dapat memberikan gambaran apakah produk yang dikembangkan layak digunakan dan di pergunakan lebih lanjut secara luas pada mata kuliah yang lain khususnya dalam pembelajaran daring di masa Covid 19 saat ini. Di lain pihak perkuliahan dengan menggunakan Moocs ini juga diharapkan dapat menjadi salah satu solusi penerapan kurikulum MBKM di Universitas Bengkulu.

\section{HASIL}

Analisis data respon uji coba terbatas pengembangan pembelajaran ilmu lingkungan menggunakan sistem MOOCs. Uji coba terbatas dilakukan untuk menguji item respon angket data respon pengembangan pembelajaran ilmu lingkungan menggunakan sistem MOOCs terhadap 20 responden dengan 14 butir soal. Penilaian menggunakan skala likert dengan skor maksimum item butir angket tersebut adalah 7 dan minimum adalah 1. Data hasil respon peserta 
ini disimpan dalam bentuk excel lalu diproses menggunakan program winstep. Dari data yang di dapat dari proses pengolahan data menggunakan winstep data variable maps seperti pada Gambar 1.

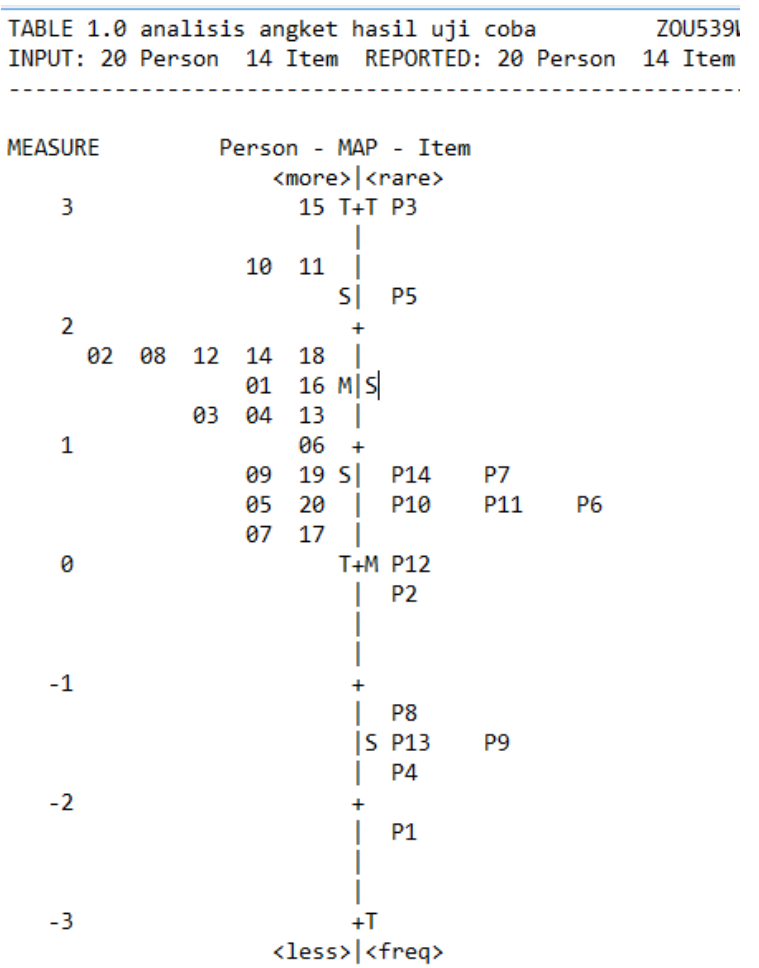

Gambar 1 Uji Variabel Maps (Person)

Pada Gambar 1 Uji Variabel Map terdiri dari measure (menunjukkan skala logit), person menunjukkan sebaran abilitas peserta, item yang menunjukkan sebaran tingkat kesulitan item butir angket yang dijawab oleh responden. Dari data di atas dapat dilihat bahwa hampir semua responden memiliki tingkat abilitas yang tinggi dalam menjawab item butir angket yang diberikan. Pada sebelah kanan peta wright terlihat 20 responden yang memiliki tingkat abilitas tertinggi salah satunya dengan kode nomor 15, 10 dan 11 dengan rata-rata logit person $+2,99$. Dari data variable map person terlihat bahwa responden/peserta yang memiliki nilai tertinggi kemampuan menjawab pertanyaan dan memiliki abilitas tertinggi ada 20 responden, dan untuk responden yang memiliki abilitas terendah adalah responden no. 07 dan 17. Dari data variable map terlihat bahwa meskipun responden no.07 dan 17 memiliki abilitas paling rendah namun tetap mampu menjawab item butir respon yang paling sulit yaitu no 03 (P3). Hal ini berarti hampir semua responden menyetujui semua item butir angket respon yang diberikan kepada peserta, hampir semua responden menyatakan bahwa pengembangan pembelajaran ilmu lingkungan menggunakan sistem MOOCs dinyatakan layak digunakan.

Kelayakan pembelajaran menggunakan MOOC juga dilaporkan Suyetno et al. (2019), pada materi pembelajaran Pengelasan. Berdasarkan data angket yang disebar didapatkan hasil bahwa MOOC yang dikembangkan Suyetno et al. (2019) memiliki angka kelayakan tinggi dengan persentase $83,22 \%$. Dengan nilai kelayakan tersebut, maka MOOC yang dikembangkan dianggap layak untuk digunakan menilai respon mahasiswa dan memiliki tingkat kelayakan yang tinggi. Berdasarkan angket yang disebar didapatkan hasil bahwa MOOC yang dikembangkan memiliki angka kemudahan penggunaan tinggi dengan persentase $84,40 \%$. Dengan tingkat kemudahan tersebut, maka MOOC yang dikembangkan dianggap layak untuk digunakan dalam penunjang perkuliahan dan mudah untuk digunakan.

Pada item butir soal angket yang memiliki tingkat abilitas tertinggi untuk dijawab oleh responden adalah no. 03 (P3 merupakan pertanyaan butir angket no 1) dengan rata-rata logit item 3,04. Pada sebelah kanan peta Wright terlihat 14 butir angket respon memiliki variabilitas tingkat kesulitan yang beragam seperti P3 dan P5 yang merupakan butir angket respon yang paling sulit, dan untuk yang memiliki abilitas butir respon paling rendah adalah P1.

Apabila kita melihat sebaran butir respon tersebut beragam dan berkelompok. Berikutnya kita akan menganalisis jarak M-S-T yang terdapat pada peta Wright di atas. Terlihat bahwa abilitas responden hanya sedikit lebih lebar dibandingkan dengan sebaran yang terdapat di tingkat kesulitan butir respon. Dalam kontek tingkat kesulitan yang terdapat di butir respon hal ini berarti butir respon soal memiliki keragaman yang tidak terlampau jauh dan abilitas responden tidak jauh berbeda. Hal ini sesuai dengan jika terdapat sebaran abilitas person yang lebih lebar dibandingkan dengan sebaran butir soal maka dapat disimpulkan 
52 JINOTEP (Jurnal Inovasi dan Teknologi Pembelajaran) Kajian dan Riset dalam Teknologi Pembelajaran Vol. 8, No. 1, Maret 2021, Hal. 47-57

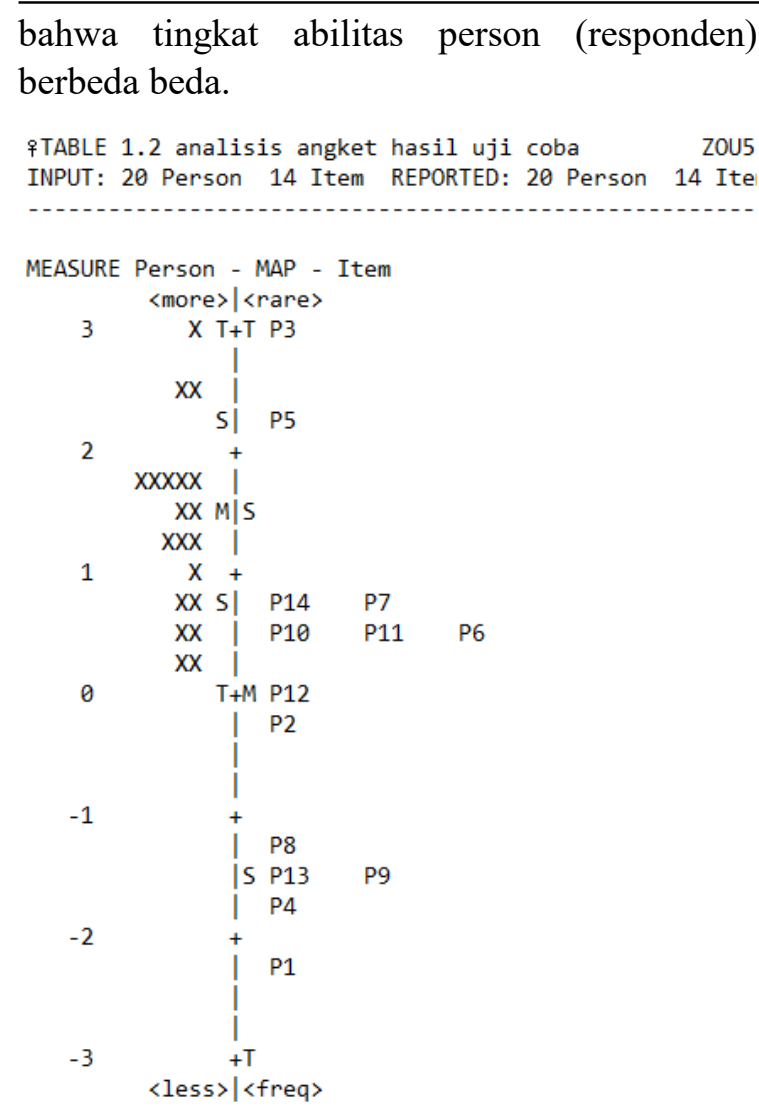

Gambar 2 Uji Variabel Maps (Item)

Analisis pada perbandingan logit person dan logit butir item/respon berdasarkan peta variabel map menunjukkan bahwa logit person jauh lebih tinggi dibandingkan dengan logit butir respon. Hal ini menunjukkan bahwa abilitas responden keseluruhan lebih tinggi daripada tarap kesulitan butir respon. Hal ini ditunjukkan dengan hampir semua responden menyetujui semua aspek butir respon yang diberikan.

Dari Gambar 3 tabel Analisis Butir Respon di atas dapat terlihat bahwa pada total count semua terisi dengan 20. Hal ini menunjukkan bahwa semua responden menjawab semua item butir yang diberikan. Dari gambar diatas dapat kita lihat pada kolom item menunjukkan tingkat kesulitan butir soal yang ditunjukkan pada kolom measure yaitu dari butir angket respon yang paling sulit yaitu $\mathrm{P} 3$ dan yang paling mudah yaitu P1. Tingkat kesulitan butir pertanyaan memudahkan kita mengidentifikasi mana soal yang sulit dan mana yang mudah.
Hal ini berbeda dengan pendekatan teori tes klasik, pada pemodelan Rasch digunakan analisis pada tingkat abilitas individu sebagai alat untuk membedakan kemampuan peserta didik yang mampu menjawab soal dan yang tidak mampu menjawab soal. Selain itu, dapat pula menggunakan cara mengidentifikasi kelompok responden berdasarkan indeks separasi responden. Semakin besar nilai separasi item maka kualitas instrumen dalam hal keseluruhan responden dan butir soal makin bagus, karena dapat mengidentifikasi kelompok responden dan kelompok butir (Sumintono \& Widhiarso, 2015).

Pada Gambar 4 tabel Tingkat Kesesuaian Soal tingkat kesesuaian pertanyaan di atas berisi tabel item fit (kesesuaian butir). Untuk menentukan data butir respon memiliki kesesuaian yang baik jika nilai Outfit Mean square $(0,5<\mathrm{MNSQ}<1,5)$, Outfit Z-standar ($2,0<$ ZSTD $<+2,0)$ dan Point measure colrrelation $(0,4<\mathrm{t}$ Measure Corer $<0,85)$ (Untary, Helverasari; Risdianto, 2020).

Dari data pada gambar 4 dapat terlihat dari seluruh butir item untuk nilai Outfit Mean Square, item no.05 memiliki MNSQ sebesar 2,64, untuk ZSTD sebesar 3,9 dan nilai Corr nya $-0,23$ semuanya melebihi kriteria yang telah ditentukan. Jadi untuk item P5 perlu untuk dikaji kembali. Jika semua nilai yang didapat tidak terdapat pada range nilai yang ditentukan, maka butir tersebut perlu dikaji kembali.

Jika terdapat 1 kriteria yang masih memenuhi dari kriteria yang dipersyaratkan maka butir soal tersebut tidak perlu diganti atau dapat tetap dipertahankan. Nilai ZSTD dipengaruhi oleh ukuran sampel. Jika kita menggunakan sampel yang sangat besar maka nilai ZSTD akan selalu di atas nilai 3. Berikut di perlihatkan kurva kesesuaian untuk butir respon no.05 pada gambar kurva di bawah ini terlihat bahwa terdapat 3 respon yang berada di luar batas ruang kepercayaan Outfit. Hal ini juga bisa ditunjukan dengan grafik ICC seperti pada gambar 5 . 
Item STATISTICS: MEASURE ORDER

\begin{tabular}{|c|c|c|c|c|c|c|c|c|c|c|c|c|c|}
\hline \multirow{3}{*}{$\begin{array}{l}\text { | ENTRY } \\
\text { | NUMBER }\end{array}$} & TOTAL & TOTAL & & MODEL | & \multicolumn{2}{|c|}{ INFIT } & \multicolumn{2}{|c|}{ OUTFIT } & \multicolumn{2}{|c|}{ |PTMEASUR-AL | } & \multicolumn{2}{|c|}{ EXACT MATCH } & \multirow[b]{2}{*}{ Item } \\
\hline & SCORE & COUNT & MEASURE & S.E. I & |MNSQ & ZSTD| & MNSQ & ZSTD| & CORR. & EXP. I & OBS\% & EXP\%| & \\
\hline & - & -1 & -1 & -- & 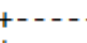 & - & +-1 & - - - & ---1 & -1 & - & $---\cdot$ & 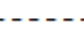 \\
\hline 3 & 59 & 20 & 3.04 & .24 & | 1.61 & 1.9 & |1.61 & 1.9 & .27 & $.57 \mid$ & 30.0 & $41.3 \mid$ & P3 \\
\hline 5 & 73 & 20 & 2.20 & .25 & 2.32 & $3.3 \mid$ & |2.64 & $3.9 \mid$ & -.23 & $.55 \mid$ & 15.0 & 40.5 & P5 \\
\hline 7 & 92 & 20 & .84 & $.29 \mid$ & .97 & .00 & .87 & $-.3 \mid$ & .51 & .48 & 60.0 & 53.4 & P7 \\
\hline 14 & 93 & 20 & .76 & .29 & .43 & -2.0 & .36 & $-2.3 \mid$ & .74 & .48 & 70.0 & 53.6 & P14 \\
\hline 6 & 95 & 20 & .58 & $.30 \mid$ & .53 & -1.5 & .51 & -1.5 & .49 & $.47 \mid$ & 70.0 & 54.0 & P6 \\
\hline 10 & 96 & 20 & .49 & $.30 \mid$ & |1.08 & $.3 \mid$ & |1.06 & $.3 \mid$ & .36 & .46 & 70.0 & 55.4 & P10 \\
\hline 11 & 96 & 20 & .49 & $.30 \mid$ & | .62 & -1.1 & | .66 & $-.9 \mid$ & .37 & .46 & 60.0 & 55.4 & P11 \\
\hline 12 & 102 & 20 & -.09 & .32 & | 1.77 & 1.8 & |1.74 & 1.7| & .54 & .45 & 25.0 & $59.7 \mid$ & P12 \\
\hline 2 & 103 & 20 & -.19 & $.32 \mid$ & .50 & $-1.6 \mid$ & | . .46 & $-1.7 \mid$ & .65 & $.46 \mid$ & 70.0 & 59.8 & P2 \\
\hline 8 & 113 & 20 & -1.16 & $.30 \mid$ & .88 & $-.3 \mid$ & .87 & $-.3 \mid$ & .61 & .49 & 55.0 & 48.5 & P8 \\
\hline 9 & 116 & 20 & -1.44 & $.30 \mid$ & .64 & $-1.4 \mid$ & .68 & $-1.1 \mid$ & .70 & .49| - 1 - & 60.0 & 47.9 & P9 \\
\hline 13 & 118 & 20 & -1.62 & $.30 \mid$ & .64 & -1.4 & .67 & $-1.2 \mid$ & .82 & .49 & 50.0 & 44.9 & P13 \\
\hline 4 & 119 & 20 & -1.71 & $.30 \mid$ & .70 & -1.2 & .75 & $-.9 \mid$ & .73 & .49 & 50.0 & 46.4 & P4 \\
\hline 1 & 124 & 20 & -2.19 & $.32 \mid$ & .79 & $-.7 \mid$ & .73 & $-.9 \mid$ & .74 & .47| & 50.0 & 42.1 & P1 \\
\hline & & & 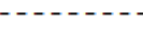 & & & -1 & 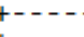 & & & & & 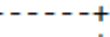 & \\
\hline MEAN & 99.9 & 20.0 & .00 & $.30 \mid$ & .96 & $-.3 \mid$ & .97 & $-.2 \mid$ & & & 52.5 & $50.2 \mid$ & \\
\hline P.SD & 17.5 & .0 & 1.46 & $.02 \mid$ & |. .54 & 1.5 & | .60 & $1.6 \mid$ & & & 17.1 & $6.3 \mid$ & \\
\hline
\end{tabular}

Gambar 3 Tabel Analisis Butir Respon

Item STATISTICS: MISFIT ORDER

\begin{tabular}{|c|c|c|c|c|c|c|c|c|c|c|c|c|}
\hline \multirow{2}{*}{$\begin{array}{l}\text { | ENTRY } \\
\text { |NUMBER }\end{array}$} & TOTAL & TOTAL & & MODEL | & \multicolumn{2}{|c|}{ INFIT } & OUTFIT & \multicolumn{2}{|c|}{ |PTMEASUR-AL | } & \multicolumn{2}{|c|}{ EXACT MATCH| } & \multirow[b]{2}{*}{ Item } \\
\hline & SCORE & COUNT & MEASURE & S.E. I & MNSQ & ZSTD & MNSQ & ZSTD|CORR. & EXP. I & OBS\% & EXP\%| & \\
\hline- & -- & & - & - & $\cdots$ & -- & $\cdots$ & 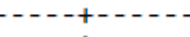 & $---t$ & 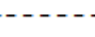 & $-\cdots--1$ & 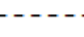 \\
\hline 5 & 73 & 20 & 2.20 & $.25 \mid$ & 2.32 & 3.3 & 2.64 & $3.9 \mid A-.23$ & $.55 \mid$ & 15.0 & $40.5 \mid$ & P5 \\
\hline 12 & 102 & 20 & -.09 & $.32 \mid$ & 1.77 & 1.8 & 1.74 & 1.7|B . .54 & $.45 \mid$ & 25.0 & $59.7 \mid$ & P12 \\
\hline 3 & 59 & 20 & 3.04 & $.24 \mid$ & 1.61 & 1.9 & 1.61 & $1.9 \mid \mathrm{C} .27$ & $.57 \mid$ & 30.0 & $41.3 \mid$ & P3 \\
\hline 10 & 96 & 20 & .49 & $.30 \mid$ & 1.08 & .3 & 1.06 & $.3 \mid D .36$ & $.46 \mid$ & 70.0 & $55.4 \mid$ & P10 \\
\hline 7 & 92 & 20 & .84 & $.29 \mid$ & .97 & .0 & .87 & $-.3 \mid \mathrm{E} .51$ & .48 & 60.0 & $53.4 \mid$ & P7 \\
\hline 8 & 113 & 20 & -1.16 & $.30 \mid$ & .88 & -.3 & .87 & $-.3 \mid F \quad .61$ & .49 & 55.0 & $48.5 \mid$ & P8 \\
\hline 1 & 124 & 20 & -2.19 & $.32 \mid$ & .79 & -.7 & .73 & $-.9 \mid G \quad .74$ & $.47 \mid$ & 50.0 & $42.1 \mid$ & P1 \\
\hline 4 & 119 & 20 & -1.71 & $.30 \mid$ & .70 & -1.2 & .75 & $-.9 \lg \quad .73$ & .49 & 50.0 & $46.4 \mid$ & P4 \\
\hline 9 & 116 & 20 & -1.44 & $.30 \mid$ & .64 & -1.4 & .68 & $-1.1 \mid f .70$ & .49 & 60.0 & $47.9 \mid$ & P9 \\
\hline 13 & 118 & 20 & -1.62 & $.30 \mid$ & .64 & -1.4 & .67 & -1.2 e .82 & .49 & 50.0 & $44.9 \mid$ & P13 \\
\hline 11 & 96 & 20 & .49 & $.30 \mid$ & .62 & -1.1 & .66 & $-.9 \mid d .37$ & .46 & 60.0 & $55.4 \mid$ & P11 \\
\hline 6 & 95 & 20 & .58 & $.30 \mid$ & .53 & -1.5 & .51 & $-1.5 \mid c .49$ & $.47 \mid$ & 70.0 & 54.0 & P6 \\
\hline 2 & 103 & 20 & -.19 & $.32 \mid$ & .50 & -1.6 & .46 & $-1.7 \mid b .65$ & .46 & 70.0 & $59.8 \mid$ & P2 \\
\hline 14 & 93 & 20 & .76 & .29 & .43 & -2.0 & .36 & $-2.3 \mid a \quad .74$ & .48 & 70.0 & $53.6 \mid$ & P14 \\
\hline MEAN & 99.9 & 20.0 & .00 & .30| & .96 & -.3 & .97 & $-.2 \mid$ & & 52.5 & 50.2 & \\
\hline P.SD & 17.5 & .0 & 1.46 & .02 & .54 & 1.5 & .60 & $1.6 \mid$ & & 17.1 & $6.3 \mid$ & \\
\hline
\end{tabular}

\section{Gambar 4 Tabel Tingkat Kesesuaian Soal}




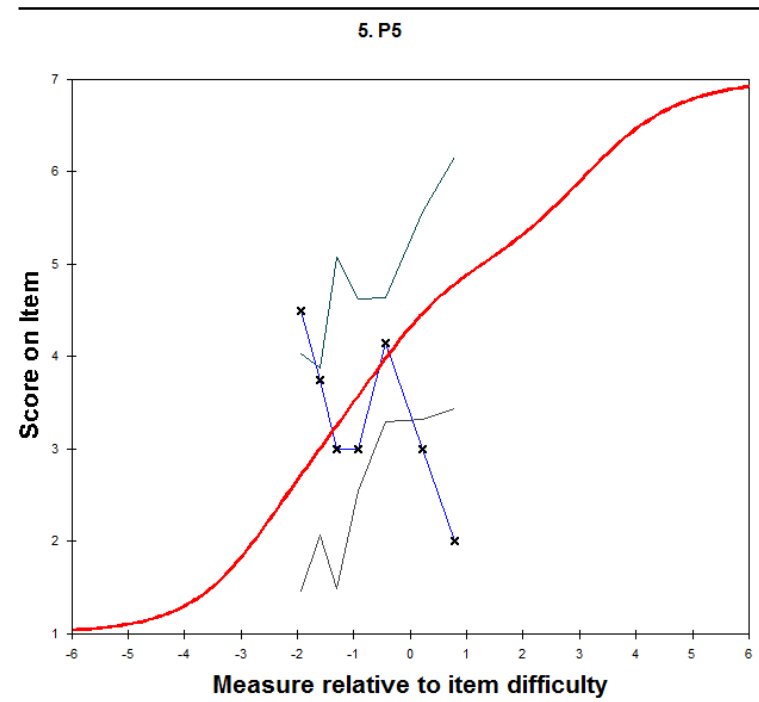

Gambar 5 Grafik Expected Score ICC

Untuk menganalisis abilitas dari responden yang mengisi butir angket kelayakan yang diberikan dapat dilihat pada gambar 6 .

Pada gambar 6 Tabel Person Measure Order kolom total count adalah jumlah butir angket di jawab oleh responden. Sedangkan kolom total score melihat total nilai yang di dapat oleh masing responden. Semua responden menjawab 14 butir angket respon yang di berikan. Pada gambar di atas pada kolom measure menunjukkan abilitas tiap responden dalam satuan logit. Responden yang memiliki nilai tertinggi ada 20 responden salah satunya adalah responden no 15 dengan nilai measure $=+2,99$, dapat dilihat pada tabel nilai infit dan outfit pada 20 responden yang memiliki abilitas tertinggi ini sudah Maximun measure. Untuk responden yang memiliki nilai terendah dengan measure $=0,22$ yaitu responden no 17. Dapat dilihat dari data di atas ada beberapa responden memiliki nilai logit yang sama, ini berarti menunjukkan bahwa skor mentah yang sama (total score) demikian pula juga abilitasnya. Untuk melihat lebih jauh mana responden yang memiliki abilitas yang lebih tinggi dapat diketahui dari skalogram. Skalogram dapat digunakan untuk melihat mana responden yang memiliki abilitas lebih tinggi meski memiliki nilai logit yang sama. Tingkat abilitas disini adalah data respon uji coba terbatas dalam menyetujui butir respon angket yang diberikan terhadap uji coba terbatas pengembangan pembelajaran ilmu lingkungan menggunakan sistem MOOCs.
Data pada gambar 7 untuk menganalisis kesesuaian responden. Disamping menganalisis abilitas responden kali ini kita juga akan menganalisis hasil kesesuaian responden. Hal ini bertujuan untuk mengetahui konsistensi berfikir dari responden dalam mengisi angket respon angket yang diberikan.

Pada gambar 7 Tabel Misfit Person di atas dapat terlihat bahwa semua responden memiliki minimal 1 nilai kriteria batas yang telah ditentukan seperti pada Tabel Misfit Person. Dan untuk melihat kesesuaian lebih lengkap dapat dilihat pada matriks Guttmann sebagaimana terlihat pada gambar 8 .

Dari gambar diatas kita dapat melihat pola jawaban dari tiap responden dapat kita lihat terdapat kemiripan jawaban antara 20 responden yang memiliki abilitas tertinggi salah satunya dari responden no 02 dan 08. Dari kemiripan pola jawaban dari responden tersebut hal ini bisa merupakan indikasi bahwa responden tersebut bisa saja saling kerjasama atau mencontek dalam pelaksanaan pengisian butir angket tersebut sehingga perlu di evaluasi atau di cross check kembali.

Dapat dilihat pada scologram memiliki pola respon yang tidak beraturan/ tidak konsisten dengan jawabanya, hal ini juga menunjukkan pada butir tertentu dia cenderung menyetujui pernyataan (mendapatkan skor butir yang tinggi/sulit) yang diajukan sedangkan pada butir lainnya cenderung menolak (mendapatkan skor butir yang rendah/mudah). Hal ini kemungkinan karena saat itu responden kurang memiliki motivasi dalam merespons skala. Rendahnya motivasi ini menyebabkan mereka memberikan respons asal-asalan. Dampaknya adalah respons mereka bervariasi dan tidak konsisten, tergantung pada mood mereka saat merespons butir. Meskipun demikian ini tidak mempengaruhi terhadap hasil respon keseluruhan (Untary, Helverasari; Risdianto, 2020). 
Person STATISTICS: MEASURE ORDER

\begin{tabular}{|c|c|c|c|c|c|c|c|c|c|c|c|c|c|}
\hline \multirow{2}{*}{$\begin{array}{l}\text { | ENTRY } \\
\text { | NUMBER }\end{array}$} & TOTAL & TOTAL & & MODEL| & \multicolumn{2}{|c|}{ INFIT } & \multicolumn{2}{|c|}{ OUTFIT } & \multicolumn{4}{|c|}{ |PTMEASUR-AL | EXACT MATCH| } & \multirow[b]{2}{*}{ Person | } \\
\hline & SCORE & COUNT & MEASURE & S.E. I & MNSQ & ZSTD & IMNSQ & ZSTD & CORR. & EXP. I & OBS\% & EXP\%| & \\
\hline & & & & & & & & & & 1 & & & \\
\hline 15 & 82 & 14 & 2.99 & .39 & $\mid 1.74$ & 1.7 & |1.74 & $1.6 \mid$ & .70 & $.73 \mid$ & 57.1 & $54.1 \mid$ & 15 \\
\hline 10 & 78 & 14 & 2.41 & $.37 \mid$ & $\mid 1.56$ & 1.4 & |1.39 & $1.0 \mid$ & .72 & $.75 \mid$ & 50.0 & $49.7 \mid$ & 10 \\
\hline 11 & 78 & 14 & 2.41 & $.37 \mid$ & .98 & .1 & .86 & $-.2 \mid$ & .94 & $.75 \mid$ & 50.0 & $49.7 \mid$ & 11 \\
\hline 2 & 74 & 14 & 1.87 & $.36 \mid$ & 2.20 & 2.4 & 1.86 & 1.8 & .80 & .75 & 28.6 & 52.4 & 02 \\
\hline 8 & 74 & 14 & 1.87 & .36 & 2.20 & 2.4 & 1.86 & $1.8 \mid$ & .80 & $.75 \mid$ & 28.6 & $52.4 \mid$ & 08 \\
\hline 14 & 74 & 14 & 1.87 & $.36 \mid$ & | .39 & -1.9 & | .34 & -2.0 & .94 & $.75 \mid$ & 71.4 & $52.4 \mid$ & 14 \\
\hline 12 & 73 & 14 & 1.74 & $.36 \mid$ & .73 & -.6 & .62 & $-.9 \mid$ & .93 & $.75 \mid$ & 50.0 & 53.0 & 12 \\
\hline 18 & 73 & 14 & 1.74 & $.36 \mid$ & .36 & -2.1 & .32 & -2.1 & .83 & $.75 \mid$ & 78.6 & 53.0 & 18 \\
\hline 1 & 72 & 14 & 1.61 & $.36 \mid$ & .24 & -2.8 & .18 & -3.0 & .91 & $.75 \mid$ & 85.7 & 53.2 & 01 \\
\hline 16 & 72 & 14 & 1.61 & $.36 \mid$ & .58 & -1.1 & .64 & $-.9 \mid$ & .82 & $.75 \mid$ & 71.4 & $53.2 \mid$ & 16 \\
\hline 4 & 70 & 14 & 1.36 & $.35 \mid$ & .32 & -2.3 & .30 & $-2.3 \mid$ & .88 & $.75 \mid$ & 71.4 & $52.2 \mid$ & 04 \\
\hline 3 & 69 & 14 & 1.24 & $.35 \mid$ & | .74 & -.6 & .73 & $-.6 \mid$ & .80 & $.75 \mid$ & 50.0 & 51.1 & 03 \\
\hline 13 & 69 & 14 & 1.24 & .35 & 1.45 & 1.1 & | 1.67 & $1.5 \mid$ & .77 & $.75 \mid$ & 64.3 & $51.1 \mid$ & 13 \\
\hline 6 & 66 & 14 & .88 & .34 & .56 & -1.2 & .59 & -1.1 & .78 & $.75 \mid$ & 50.0 & 49.2 & 06 \\
\hline 9 & 65 & 14 & .77 & $.34 \mid$ & | .62 & -1.0 & .57 & $-1.2 \mid$ & .74 & $.75 \mid$ & 64.3 & $45.9 \mid$ & 09 \\
\hline 19 & 64 & 14 & .66 & .34 & 1.09 & .4 & .93 & -.1 & .55 & $.75 \mid$ & 35.7 & $44.2 \mid$ & 19 \\
\hline 20 & 63 & 14 & .54 & $.33 \mid$ & .61 & -1.1 & .58 & -1.2 & .76 & $.75 \mid$ & 42.9 & $46.4 \mid$ & 20 \\
\hline 5 & 62 & 14 & .43 & $.33 \mid$ & | .41 & -1.9 & .39 & -2.0 & .82 & $.75 \mid$ & 64.3 & 46.9 & 05 \\
\hline 7 & 61 & 14 & .32 & $.33 \mid$ & 1.92 & 2.1 & 2.06 & $2.2 \mid$ & -.22 & $.76 \mid$ & 14.3 & $47.1 \mid$ & 07 \\
\hline 17 & 60 & 14 & .22 & $.33 \mid$ & 1.92 & 2.1 & 1.78 & $1.8 \mid$ & .76 & $.76 \mid$ & 21.4 & 47.0 & 17 \\
\hline MEAN & 70.0 & 14.0 & 1.39 & $.35 \mid$ & 1.03 & -.1 & .97 & -.3 & & & 52.5 & 50.2 & \\
\hline P.SD & 6.0 & .0 & .74 & .02 & | .66 & 1.7 & .62 & 1.6 & & & 19.1 & 2.9 & \\
\hline
\end{tabular}

\section{Gambar 6 Tabel Person Measure Order}

Person STATISTICS: MISFIT ORDER

\begin{tabular}{|c|c|c|c|c|c|c|c|c|c|c|c|c|c|}
\hline \multirow{2}{*}{$\begin{array}{l}\text { | ENTRY } \\
\text { | NUMBER }\end{array}$} & \multirow{2}{*}{$\begin{array}{l}\text { TOTAL } \\
\text { SCORE }\end{array}$} & \multirow{2}{*}{$\begin{array}{l}\text { TOTAL } \\
\text { COUNT }\end{array}$} & \multirow[b]{2}{*}{ MEASURE } & \multirow{2}{*}{$\begin{array}{l}\text { MODEL } \\
\text { S.E. }\end{array}$} & \multicolumn{2}{|c|}{ INFIT } & \multicolumn{2}{|c|}{ OUTFIT } & \multicolumn{4}{|c|}{ |PTMEASUR-AL|EXACT MATCH| } & \multirow[b]{2}{*}{ Person } \\
\hline & & & & & MNSQ & ZSTD & IMNSQ & ZSTD|C & CORR. & EXP. & OBS\% & EXP\% & \\
\hline 2 & 74 & 14 & 1.87 & .36 & 2.20 & 2.4 & 1.86 & $1.8 \mid \mathrm{A}$ & A .80 & .75 & 28.6 & 52.4 & 02 \\
\hline 8 & 74 & 14 & 1.87 & .36 & 2.20 & 2.4 & 1.86 & $1.8 \mid \mathrm{B}$ & B .80 & .75 & 28.6 & 52.4 & 08 \\
\hline 7 & 61 & 14 & .32 & $.33 \mid$ & 1.92 & 2.1 & 2.06 & $2.2 \mid \mathrm{C}$ & $C-.22$ & .76 & 14.3 & 47.1 & 07 \\
\hline 17 & 60 & 14 & .22 & $.33 \mid$ & 1.92 & 2.1 & 1.78 & $1.8 \mid \mathrm{D}$ & D. .76 & .76 & 21.4 & 47.0 & 17 \\
\hline 15 & 82 & 14 & 2.99 & .39 & 1.74 & 1.7 & 1.74 & $1.6 \mid \mathrm{E}$ & E. .70 & .73 & 57.1 & 54.1 & 15 \\
\hline 13 & 69 & 14 & 1.24 & $.35 \mid$ & 1.45 & $1.1 \mid$ & 1.67 & $1.5 \mid \mathrm{F}$ & $F .77$ & .75 & 64.3 & 51.1 & 13 \\
\hline 10 & 78 & 14 & 2.41 & .37 & 1.56 & 1.4 & 1.39 & $1.0 \mid \mathrm{G}$ & G . . 72 & .75 & 50.0 & 49.7 & 10 \\
\hline 19 & 64 & 14 & .66 & .34 & 1.09 & .4 & .93 & $-.1 \mid \mathrm{H}$ & H. .55 & .75 & 35.7 & 44.2 & 19 \\
\hline 11 & 78 & 14 & 2.41 & $.37 \mid$ & .98 & .1 & .86 & $-.2 \mid \mathrm{I}$ & I . .94 & .75 & 50.0 & 49.7 & 11 \\
\hline 3 & 69 & 14 & 1.24 & .35 & .74 & -.6 & .73 & $-.6 \mid \mathrm{J}$ & ] .80 & .75 & 50.0 & 51.1 & 03 \\
\hline 12 & 73 & 14 & 1.74 & $.36 \mid$ & .73 & -.6 & .62 & $-.9 \mid j$ & j. .93 & .75 & 50.0 & 53.0 & 12 \\
\hline 16 & 72 & 14 & 1.61 & .36 & .58 & -1.1 & .64 & $-.9 \mid i$ & i. .82 & .75 & 71.4 & 53.2 & 16 \\
\hline 9 & 65 & 14 & .77 & .34 & .62 & -1.0 & .57 & $-1.2 \mid \mathrm{h}$ & h . .74 & .75 & 64.3 & 45.9 & 09 \\
\hline 20 & 63 & 14 & .54 & $.33 \mid$ & .61 & -1.1 & .58 & $-1.2 \mid \mathrm{g}$ & g .76 & .75 & 42.9 & 46.4 & 20 \\
\hline 6 & 66 & 14 & .88 & .34 & .56 & -1.2 & .59 & $-1.1 \mid f$ & f . 78 & .75 & 50.0 & 49.2 & 06 \\
\hline 5 & 62 & 14 & .43 & $.33 \mid$ & .41 & -1.9 & .39 & $-2.0 \mid \mathrm{e}$ & e .82 & .75 & 64.3 & 46.9 & 05 \\
\hline 14 & 74 & 14 & 1.87 & .36 & .39 & -1.9 & .34 & $-2.0 \mid \mathrm{d}$ & d .94 & .75 & 71.4 & 52.4 & 14 \\
\hline 18 & 73 & 14 & 1.74 & .36 & .36 & -2.1 & .32 & $-2.1 \mid c$ & c . .83 & .75 & 78.6 & 53.0 & 18 \\
\hline 4 & 70 & 14 & 1.36 & .35 & .32 & -2.3 & .30 & $-2.3 \mid b$ & b . 88 & .75 & 71.4 & 52.2 & 04 \\
\hline 1 & 72 & 14 & 1.61 & $.36 \mid$ & .24 & -2.8 & .18 & $-3.0 \mid a$ & a . .91 & $.75 \mid$ & 85.7 & 53.2 & 01 \\
\hline & & & & & & & & & & & & & \\
\hline MEAN & 70.0 & 14.0 & 1.39 & $.35 \mid$ & 1.03 & $-.1 \mid$ & .97 & $-.3 \mid$ & & & 52.5 & 50.21 & \\
\hline P.SD & 6.0 & .0 & .74 & .021 & .66 & 1.7 & .62 & $1.6 \mid$ & & & 19.1 & 2.9 & \\
\hline
\end{tabular}


56 JINOTEP (Jurnal Inovasi dan Teknologi Pembelajaran) Kajian dan Riset dalam Teknologi Pembelajaran Vol. 8, No. 1, Maret 2021, Hal. 47-57

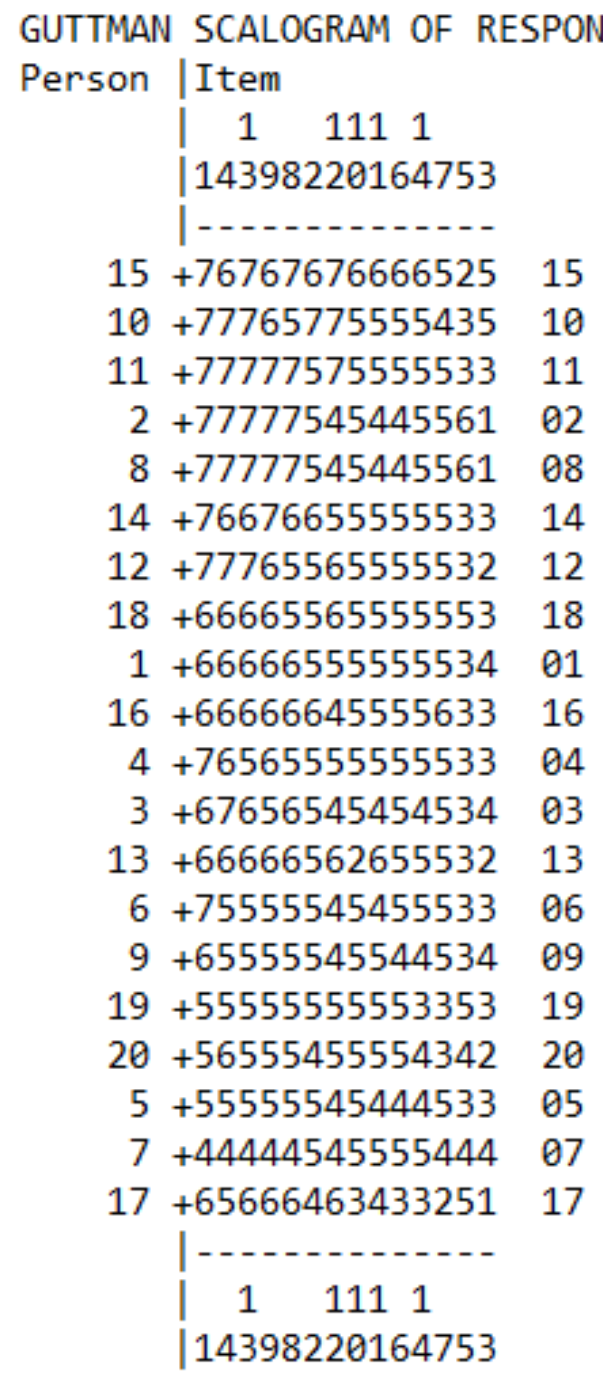

Gambar 8 Scalogram

\section{SIMPULAN}

Dari analisis yang telah dilakukan berdasarkan angket analisis item respon angket data respon uji coba terbatas pengembangan pembelajaran ilmu lingkungan menggunakan sistem MOOCs ini maka dapat disimpulkan bahwa kualitas dari angket respon terhadap uji coba terbatas pengembangan pembelajaran ilmu lingkungan menggunakan sistem MOOCs ini adalah sangat baik. Sehingga dapat digunakan untuk menguji coba terbatas pengembangan pembelajaran ilmu lingkungan menggunakan sistem MOOCs.

Hasil analisis terhadap responden dan item butir angket menunjukkan bahwa mayoritas responden menyetujui semua butir angket yang diberikan sehingga menunjukkan bahwa pengembangan pembelajaran ilmu lingkungan menggunakan sistem MOOCs ini layak digunakan. Meskipun demikian perlu dilakukan penelitian lebih lanjut untuk menguji keefektifan pengembangan pembelajaran ilmu lingkungan menggunakan sistem MOOCs ini dapat digunakan untuk jenis materi matakuliah yang lain khususnya dalam pembelajaran daring di masa Covid 19 saat ini.

\section{UCAPAN TERIMA KASIH}

Terimakasih penulis ucapkan pada Belmawa Kemdikbud yang telah mendanai kegiatan ini melalui program Pengembangan dan Penyelenggaraan Inovasi Pembelajaran Digital.

\section{DAFTAR RUJUKAN}

Arifin, S., \& Muslim, M. O. H. (2020). Tantangan Implementasi Kebijakan "Merdeka Belajar, Kampus Merdeka" pada Perguruan Tinggi Islam Swasta di Indonesia. Jurnal Pendidikan Islam Al-Ilmi, 3(1).

Azri, N., Halim, A. A., Othman, N., \& Manusia, F. E. (2020). Pembelajaran Bercirikan Kepelbagaian Dan Global Dalam. Jurnal Wacana Sarjana, 4(June), 1-9.

Busri, E., Zulirfan, Z., \& Fakhruddin, F. (2019). The Development of MOOC Media to Increase Recall Memory Skill on Physics at Vocational High School. Journal of Physics: Conference Series, 1(1), 1-4. https://doi.org/10.1088/17426596/1351/1/012017

Cormier, D., Stewart, B., Siemens, G., \& McAuley, A. (2010). What is a MOOC?

Emigawaty. (2017). Perancangan Arsitektur dan Purwarupa Model Pembelajaran Massive Open Online Course (Moocs) Di Perguruan Tinggi Menggunakan Layanan Mobile. Jurnal Ilmiah DASI, 18(1), 25-30.

Enersy, D., Karyadi, B., \& Winarni, E. W. (2017). Studi Komunitas Nekton Di Kawasan Konservasi Kura-Kura Universitas Bengkulu Dan Pengembangan Pembelajaran Berbasis Lingkungan. PENDIPA Journal of Science Education, 1(1), 55-61.

Hu, H. (2013). MOOC migration. Diverse Issues in Higher Education, 30(4), 10.

Husna, J. (2019). Implementasi MOOCs di Pendidikan Ilmu Perpustakaan dan Informasi (Sebuah Peluang dan Tantangan di Indonesia). Anuva: Jurnal Kajian Budaya, Perpustakaan, Dan Informasi, 3(3), 247-256.

Ismail, M. E., Hashim, S., Ismail, I. M., Ismail, A., Daud, K. A. M., \& Khairudin, M. (2018). Penggunaan Massive Open Online Course (Mooc) Dalam Kalangan Pelajar Vokasional. Journal of Nusantara Studies, 3(1), 30-41. 
Ismail, M. E., Utami, P., Ismail, I. M., Hamzah, N., \& Harun, H. (2018). Development of massive open online course (MOOC) based on addie model for catering courses. Jurnal Pendidikan Vokasi, 8(2), 184-192. https://doi.org/10.21831/jpv.v8i2.19828

Johan, R. C. (2016). Massive Open Online Course (Mooc) Dalam Meningkatkan Kompetensi Literasi Informasi Guru Pustakawan Sekolah. Pedagogia Jurnal Ilmu Pendidikan, 13(1), 203-213.

https://doi.org/10.17509/pedagogia.v13i1.3382

Johar, A., Risdianto, E., \& Indriyati, D. A. F. (2014). Perancangan Dan Implementasi Media Pembelajaran Berbasis Web Pada Bidang Studi Bahasa Inggris Di Kelas Vii Smp Negeri 1 Kota Bengkulu Dengan Menggunakan Php Dan Mysql. Rekursif, 2(1), 1-9.

Korpershoek, H., Kuyper, H., Bosker, R., \& van der Werf, G. (2013). Students' preconceptions and perceptions of science-oriented studies. International Journal of Science Education, 35(14), 2356-2375.

Peranti, Purwanto, A., \& Risdianto, E. (2019). Pengembangan Media Pembelajaran Permainan Mofin (Monopoli Fisika Sains) Pada Siswa SMA Kelas X. Jurnal Kumparan Fisika, 2(1), 41-47.

Praherdhiono, H., Adi, E. P., \& Prihatmoko, Y. (2018). Konstruksi Demokrasi Belajar Berbasis Kehidupan Pada Implementasi LMS dan Mooc. Edcomtech, 3(1), 21-28.

Putri, R. M., Risdianto, E., \& Rohadi, N. (2019). Pengembangan Media Pembelajaran Interaktif Dengan Menggunakan Adobe Captivate Pada Materi Gerak Harmonik Sederhana. Jurnal Kumparan Fisika, 2(2), 113-120. https://doi.org/10.33369/jkf.2.2.113-120

Rafiq, K. R. M., Hashim, H., Yunus, M. M., \& Pazilah, F. N. (2019). Developing a MOOC for communicative english: A battle of instructional designs. International Journal of Innovation, Creativity and Change, 7(7), 2939.

Risdianto, E. (2019). Development of Blended Learning Based on Web and Augmented Reality. 1st International Conference on
Educational Sciences and Teacher Profession (ICETeP 2018), 295, 144-147.

Risdianto, E., Dinissjah, M. J., \& Kristiawan, M. (2020). The Effect of Ethno Science-Based Direct Instruction Learning Model in Physics Learning on Students ' Critical Thinking Skill. Universal Journal of Educational Research, $8(2)$, 611-615. https://doi.org/10.13189/ujer.2020.080233

Rodriguez, C. O. (2012). MOOCs and the AIStanford Like Courses: Two Successful and Distinct Course Formats for Massive Open Online Courses. European Journal of Open, Distance and E-Learning.

Shah, D. (2019). By The Numbers: MOOCs in 2019. Class Central. https://www.classcentral.com/report/moocstats-2019/\#: :text=MOOCs in 2015,Courses,were launched by 450 universities.

Siahaan, A. D., Medriati, R., \& Risdianto, E. (2019). Pengembangan Penuntun Praktikum Fisika Dasar Ii Menggunakan Teknologi Augmented Reality Pada Materi Rangkaian Listrik Dan Optik Geometris. Jurnal Kumparan Fisika, 2(2), $\quad$ 91-98. https://doi.org/10.33369/jkf.2.2.91-98

Sintia, W., Hamdani, D., \& Risdianto, E. (2018). Rancang Bangun Sistem Monitoring Kelembaban Tanah dan Suhu Udara Berbasis GSM SIM900A dan Arduino Uno. Jurnal Kumparan Fisika, 1(2), 60-65.

Siregar, N., Sahirah, R., \& Harahap, A. A. (2020). Konsep Kampus Merdeka Belajar di Era Revolusi Industri 4.0. Fitrah: Journal of Islamic Education, 1(1), 141-157.

Sriwahyuni, I., Risdianto, E., \& Johan, H. (2019). Pengembangan Bahan Ajar Elektronik Menggunakan Flip Pdf Professional Pada Materi Alat-Alat Optik Di Sma. Jurnal Kumparan Fisika, 2(3), 145-152. https://doi.org/10.33369/jkf.2.3.145-152

Untary, Helverasari; Risdianto, E. dan K. (2020). Analisis Data Penelitian dengan Model Rasch dan Winstep. Halaman Moeka.

Yuan, L., \& Powell, S. J. (2013). MOOCs and open education: Implications for higher education. 